\title{
Morphodynamics of a wave dominated embayed beach on an irregular rocky coastline
}

\author{
Mario Luiz Mascagni ${ }^{1 *}$, Eduardo Siegle ${ }^{l}$, Moysés Gonsalez Tessler ${ }^{1}$, Samara Cazzoli y Goya \\ ${ }^{1}$ Instituto Oceanográfico da Universidade de São Paulo \\ (Praça do Oceanográfico, 191 - Butantã - SP - 05508-120 - Brazil) \\ *Corresponding author: tatramario@gmail.com
}

\section{Abstract}

Wave-dominated embayed beaches on irregular rocky coastlines are highly appreciated for their landscapes and tourism potential. Yet our understanding about the interaction of the oceanographic processes with the geological inheritance in this type of beaches still needs further investigation to better understand their natural balance. In this study, we apply the classical approach of morphodynamics to describe for the first time the variations in the Boiçucanga beach morphology, an embayed beach located in São Sebastião City on an irregular rocky coastline that is well known for its beautiful beaches embedded in the valleys of Serra do Mar. Field surveys were performed over 15 months, between April 2008 and September 2009, seeking to evaluate the interactions among the morphology, sediments and hydrodynamic characteristics at Boiçucanga. All data generated during the field surveys have supported the application of the following morphodynamic models: Classification of morphological beach stages [O]; Number of nearshore sandbars [B*]; Relative tide range [RTR]; Beach exposure on embayed coasts [Ro/a and B]; and Embayment beach scaling parameter [d] to determine the geomorphological behavior of the beach on monthly and annual time scales. From these models, Boiçucanga is classified as a deep embayed beach exposed to highenergy waves, with a predominant reflective profile, which favors the development of beach cusps and topographically controlled rip currents. The combined results of the field observations and applied models allowed us to better understand the role of geological heritage in the two morphodynamic signatures found at the same beach arch. For future studies, we will focus on numerical models to increase the understanding of the hydrodynamic processes that govern the sediment transport in Boiçucanga.

Descriptors: Geological inheritance, Geomorphology, Sediment transport, Morphoscopy, Granulometry.

\section{Resumo}

Praias dominadas por ondas ao longo de litorais rochosos recortados são consideradas de grande potencial turístico, devido a beleza de seus recursos naturais. A compreensão das interações entre os processos oceanográficos, geomorfológicos e a herança geológica dominante neste tipo de praias ainda requer maiores investigações que permitam qualificar nossa compreensão e ajudar a preservar o equilíbrio dinâmico natural destes ambientes. Através da abordagem morfodinâmica clássica, descrevemos pela primeira vez as variações morfológicas da praia de Boiçucanga, localizada em uma baía entre promontórios rochosos no município de São Sebastião, SP; região conhecida por belas praias arenosas incrustadas nos vales da Serra do Mar. Foram realizados levantamentos morfológicos ao longo de 15 meses, entre abril de 2008 e setembro de 2009, buscando avaliar as relações entre a morfologia e as características hidrodinâmicas e sedimentares da praia de Boiçucanga. Os dados de campo permitiram a aplicação de modelos da literatura clássica de morfodinâmica praial, como: classificação de estágios morfológicos; número de bancos; altura relativa da maré; grau de exposição da praia; e o grau de embaiamento da praia. A combinação dos resultados dos levantamentos de campo, em especial dos perfis morfológicos da praia e das caracteríscas dos sedimentos na zona de espraiamento, bem como a aplicação dos modelos morfodinâmicos clássicos, permitiram uma melhor compreensão do papel da herança geológica - posição e alcance dos promontórios mar adentro - sobre as assinaturas morfodinâmicas encontradas ao longo do arco praial de Boiçucanga; sendo uma assinatura mais energética com tendências refletivas, favorecendo o desenvolvimento de feições praiais rítmicas (e.g. cúspides praiais) e correntes de retorno controladas pela topografia, e outra menos energética com tendências dissipativas.

Descritores: Herança geológica, Geomorfologia, transporte de sedimentos, Morfoscopia, Granulometria. 


\section{INTRODUCTION}

Beach morphodynamics refers to the dynamic interactions between hydrodynamic processes and sediments disposed on the beach profile (Short and Jackson, 2013). Short (1999a) suggests the following five major parameters to describe beach systems: 1 - tidal range, 2 - wave height, 3 - wave period, 4 - sediment grain size/shape and 5 - beach length/embayment. The complex interrelationships among these five parameters are the object of study for the classical school of beach morphodynamics, which has developed some mathematical models to describe the morphodynamic behavior of beach systems (Short, 1999a).

The classification of morphological beach stages [Q] (Wright and Short, 1984), the numbers of nearshore sandbars [B*] (Short and Aagaard, 1993), the relative tide range [RTR] (Masselink and Short, 1993), the beach exposure in embayed coasts [Ro/a and $\beta]$ (Silvester and Hsu, 1997) and the embayment beach scaling parameter

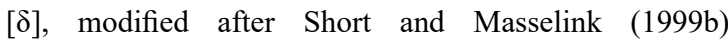
by Castelle and Coco (2012), are among the most representative models of the classical morphodynamics approach, all widely cited in the specialized literature. These specific models were chosen for this study because they are complementary to each other, forming a very important set of tools for integrated analysis of beach systems, when applied jointly. Hence, we have applied the above mentioned models to describe, for the first time, the dynamic morphology of Boiçucanga, an embayed beach located on the north shore of São Paulo, Brazil; a wellknown region for its natural beauties and its role as an important tourist location in the local economy.

Embayed beaches are sectors of the coastline that have developed a curved morphology in the presence of hard rock headlands (Short and Masselink, 1999b). When these environments are wave-dominated, they have large spatial and temporal variabilities and are rich in natural resources, which - if not respected in their particularities - may become precursors of a series of environmental problems related to the instability of the shoreline and the protection of land areas, thus compromising the aesthetic and environmental quality of these systems (Tessler and Goya, 2005).

To better understand embayed beach dynamics, studies based on field observations were performed during the last two decades: Klein et al. (2002) studied beach rotation in south Brazil; Dehouck et al. (2009) focused on the nearshore current structure; Dai et al. (2010) studied sediment transport influenced by variations in the wave climate; Martins et al. (2010) addressed storm impacts on the beach morphology on a monthly time scale and Price and Ruessink (2011) worked on the transition state based on the morphological beach stages.

According to Short and Masselink (1999b) approximately $51 \%$ of the world's coastline presents headland bay beach morphology. Hence, morphodynamics studies of embayed beaches, such as Boiçucanga, are very important for assessing their morphological evolution and identifying possible imbalances in their natural dynamics, e.g., chronicle erosion and flooding processes over urban structures, such as roads, houses, buildings, and marinas, before they evolve to natural disasters (Muehe, $2005 ; 2006$ ).

The main objective of this study is to gain insights about the short- (monthly) and medium-term (year) morphodynamic balances of embayed beaches, taking Boiçucanga as our case study due to its importance to the local economy and its representativeness of embayed beach systems. Boiçucanga is situated in the middle of one of the most irregular coastlines of Brazil. All data that have supported this study were based on field surveys at Boiçucanga beach that were performed monthly for 15 months between April 2008 and September 2009.

\section{MATERIAL AND METHODS}

\section{STUDY SITE}

Boiçucanga is a small beach (1.9 km long) encrusted in the valleys of the crystalline hills of Serra do Mar in São Sebastião City, on the northern coast of São Paulo, Brazil. Boiçucanga beach is mainly south-facing in a region constantly under the influence of storm waves. Large cyclonic systems moving from high to low latitudes in the southern hemisphere are responsible for developing storm waves and heavy rainfall events, which are also influenced by the geography of the steep hills of Serra do Mar (Figure 1). Serra do Mar is a set of high and steep crystalline structures that borders the southern and southeastern Brazilian coast and extends over $1000 \mathrm{~km}$, largely covered by dense tropical vegetation (Almeida and Carneiro, 1998).

Similar to the other beaches in the region, Boiçucanga has a small river called Rio Grande that flows into the sea at the eastern end of the beach. This small river has an average flow of $1.48 \mathrm{~m}^{3} / \mathrm{s}$, which is considered a very 

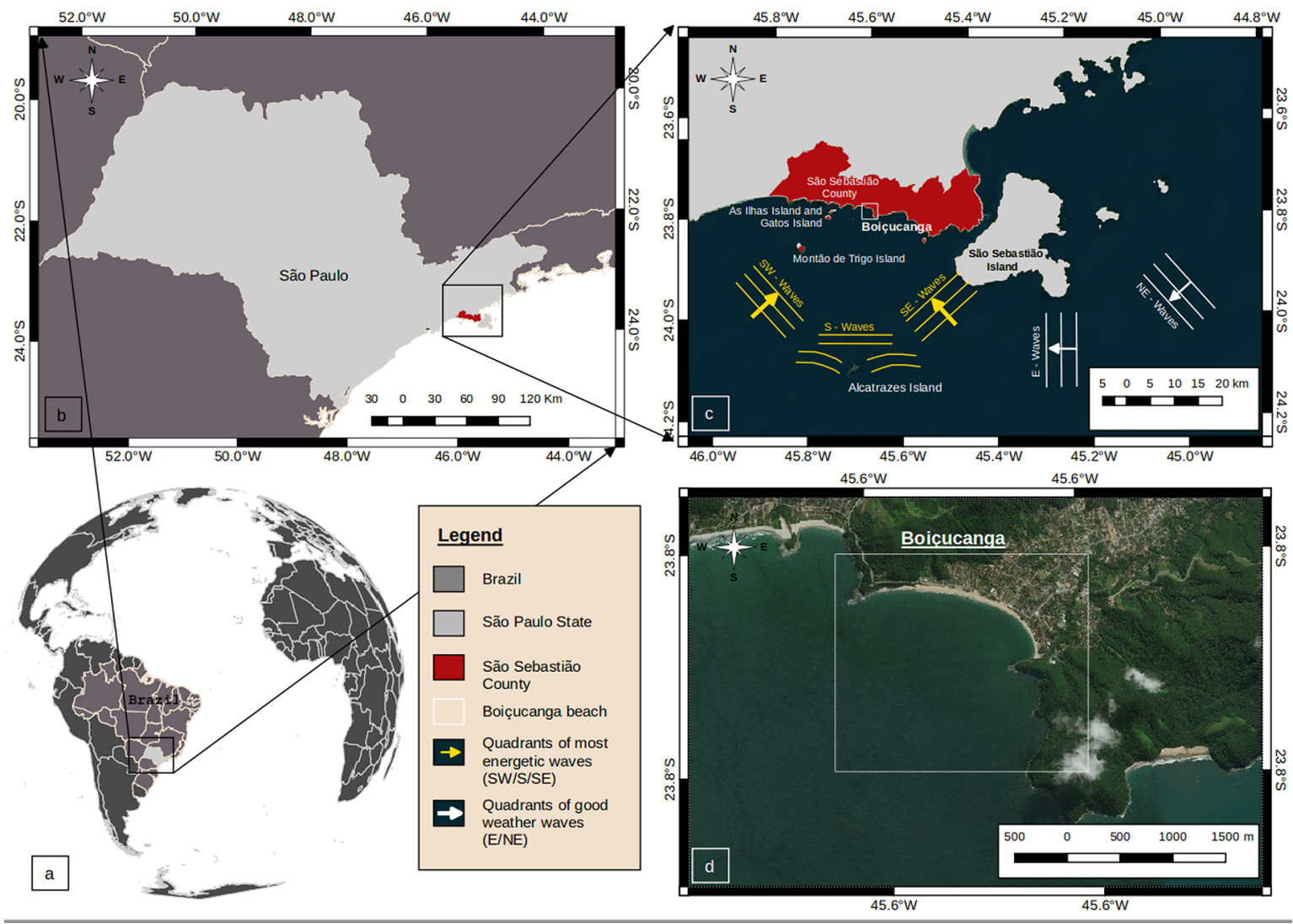

Figure 1. Boiçucanga beach and the regional swells that reach the beach's face coming from S, SW, and WE. Swells from E and NE are largely refracted and reach the beach with very low energy.

low discharge (IPT, 2000). Silveira (1964) characterized the geographic region of the study area as an irregular shoreline surrounded by headlands, with an average height of $800 \mathrm{~m}$, and several small rock islands on the ocean side. These islands play an important role in the coastal dynamics by modifying the local patterns of winds and waves that propagate towards the study area.

The climate in the Boiçucanga region is classified as subtropical, hot and humid, without a dry season. It rains more than $1500 \mathrm{~mm} / \mathrm{m}^{3}$ per year, and the average temperature is approximately $24^{\circ} \mathrm{C}$ (Sant'Anna Neto, 2005; Rolim et al., 2007). Boiçucanga is located in a microtidal region with a water level variation of approximately $0.9 \mathrm{~m}$ (Miranda et al., 2002). The tides are semidiurnal and range between $0.7 \mathrm{~m}$ and $1.2 \mathrm{~m}$ during neap and spring tides, respectively. The effects of storm surges are not yet quantified for the study site, but based on field observations, it is expected that this phenomenon may at least double the maximum range of the astronomical tide. The swell waves that reach the Boiçucanga region (Figure 1) are mainly formed by the
South Atlantic Subtropical Anticyclone; these waves mainly come from the $\mathrm{N}, \mathrm{NE}$ and $\mathrm{E}$ directions, with average heights of approximately $0.5 \mathrm{~m}$ and long periods (12-16 seconds). The storm waves are mainly generated by the South Atlantic Polar Anticyclones; these waves come from the S, SE and SW directions, and they usually have heights above $2 \mathrm{~m}$ and short periods (4-12 seconds) (Pianca et al., 2010).

\section{FIELD SURVEYS}

A 15-month field survey was performed during low spring tides for 10 consecutive months between April 2008 and January 2009, and subsequently for 5 months between May 2009 and September 2009. The exact dates of the field surveys are presented in Table 2 in the results section of this work.

Boiçucanga beach was divided into the following four sectors: A, B, C and D. The initial hypothesis was that these sectors would supposedly present some different morphodynamic characteristics due to the coastline 
orientation. In each of these sectors, a profile of the beach's surface was monitored from the upper limit at the rear of the storm berm to the breaker zone - when the sea conditions were safe to reach it.

The positions of the beach profiles were chosen to cover the main morphological features observed in the Boiçucanga coastal plain, according to the methods described in Muehe (1996). The base point of each beach profile was georeferenced using a Garmin $72 \mathrm{H}$ Waterproof Handheld GPS. A direct transposition of each of these base points to the closest geodesic mark of IBGE (Brazilian Institute of Geography and Statistics) in Boiçucanga (M-33A / B-O-780/2.002) was performed using a Leica optical theodolite, with an increase of $30 \mathrm{X}$ and an accuracy of $2.4 \mathrm{~cm}$, and a $5 \mathrm{~m}$ topographic ruler. These transpositions are important to correct the altitude of the monitored beach profiles.

The beach profiles were also monitored with the theodolite and the topographic ruler. The direction of each profile was corrected in all field surveys with the use of a Mini Boat compass, with tilt and steering adjustments. The geographic coordinate systems used were the WGS84 (EPSG:4326) and SAD69 datum. Figure 2 shows the beach sectors, profile positions, and geographical locations of the base points of the profiles and the compass steering for each of the monitored profiles and the location of the geodesic mark in Boiçucanga.

\section{SEDiment ANALYSis}

In addition to the morphological measures, sediment samples were collected in the swash zone of all the beach profiles. These samples were statistically and morphoscopically analyzed following the methods described in Suguio (1973). In the laboratory, the samples were oven dried at $60^{\circ} \mathrm{C}$; then, $100 \mathrm{~g}$ of the dry samples was separated for the granulometric analysis. After the initial drying, a solution of $10 \% \mathrm{HCl}$ was placed in a graduated beaker with the dry samples to remove the $\mathrm{CaCO}_{3}$. Subsequently, the samples were dried and weighed again. The new dry samples were sieved, with the aid of a mechanical stirrer and a succession of dry sieves of different mesh sizes down to a minimum fraction of 0.062 $\mathrm{mm}$. This corresponds to the fraction of fine materials according to the classification of Wentworth (1922). An initial sediment analysis showed that there was no need to apply wet sieving and pipetting techniques because of the negligible amount of fine materials in the samples. The results obtained by the sieve analysis were inserted into the GRANULO V.1 software - BORLAND Inc. (1983) to determine the original statistics parameters of Folk and Ward (1957).

The sand fractions separated by the sieves of 0.500 and $0.250 \mathrm{~mm}$ for all samples were morphoscopically analyzed with an optical loupe (40X magnification), using the Russell-Taylor-Pettijohn roundness charts in Muller (1967), and the sphericity parameter of the quartz grain was analyzed using the Rittenhouse (1943) sphericity chart.

\section{WAVE CLIMATE}

To complement the field surveys, some remote databases were used, such as the main wave parameters from NOAA Wavewatch III (WW3), a well-known numerical model for wave forecasting, and some satellite images available on the Google Earth Pro and Bing web platforms. The WW3 wave height, peak period and direction from April 2008 to September 2009 were obtained from the official NOAA ftp repository - ftp:// polar.ncep.noaa.gov/pub/history/waves/multi_1/.

For Boiçucanga, the $45^{\circ} 45^{\prime} 0.00^{\prime \prime} \mathrm{W}$ longitude and the $25^{\circ} 00^{\prime} 0.00^{\prime \prime} \mathrm{S}$ latitude point was chosen from a $00^{\circ} 30^{\prime}$ degree resolution of a regular grid of the whole world in a GRIB format file. This specific coordinate point was chosen to represent the wave parameters in deep water for the Boiçucanga region because the WW 3 v3.14 model does not solve the shallow water equations for wave propagation. WGRIB2 software was used to extract the significant heights, peak periods and wave directions from the GRIB files for the desired geographic positions. The sampling frequency of the collected wave data is every 3 hours.

The wave height events over $2.5 \mathrm{~m}$ and the wave propagation directions from $135^{\circ}$ to $270^{\circ}$ that occurred in deep water $(\sim 80 \mathrm{~m}$ deep) were selected from the downloaded WW3 data. These directions were chosen because of the geographic position of Boiçucanga; Figure 1C shows that all other directions would not reach Boiçucanga beach because of its natural shelter. The wave heights over $2.5 \mathrm{~m}$ were chosen by empirical analysis, mainly by the comparison of the visual observations of wave height, direction and period during the field surveys with the processed WW3 data.

The visual observations of the wave parameters in the surf zone during the field surveys were performed as described in Muehe (1998). The topographic ruler was positioned at the break point of the waves in the 


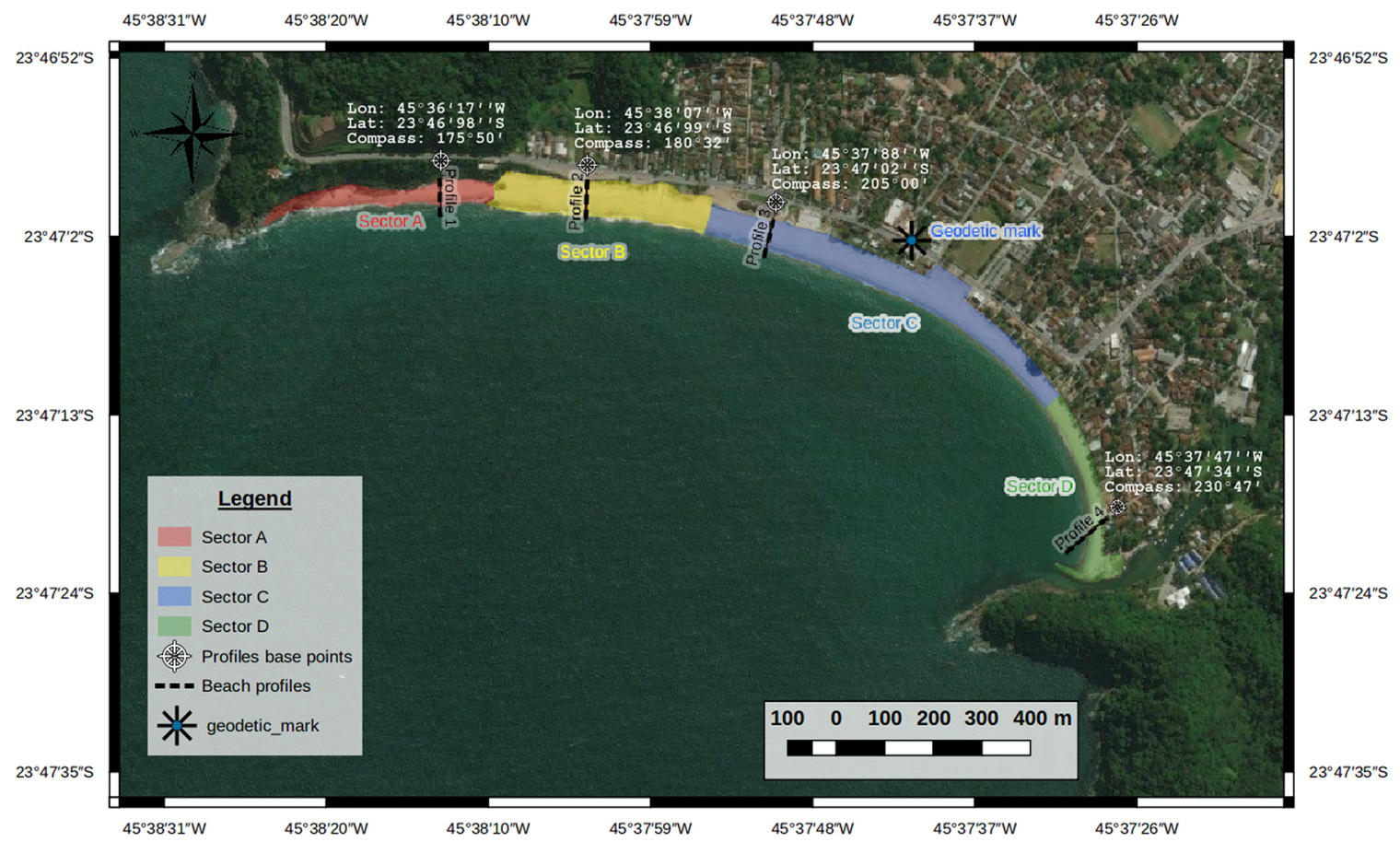

Figure 2. Beach sectors, beach profiles, base point of the beach profiles and the IBGE geodesic mark position used to georeference the field data.

surf zone at Boiçucanga beach in front of each beach profile monitored during the field surveys, when the hydrodynamic conditions were safe for measurement. Two observers took visual measurements from 11 consecutive wave peaks propagating passed the ruler. The observers took notes of the wave heights, periods and directions. Later, they calculated the mean wave heights, periods and directions from the 20 waves observed, 10 for each observer.

\section{REMOTE SENSING}

Regarding the satellite images, we used the Bird Eye satellite high-resolution image from Bing to plot the study site area, but were used mainly the Google Earth images from the historical imagery toolbar to observe the wave directions that reach Boiçucanga beach. This tool has provided annual images of the Boiçucanga region from 1984 to the current year, with a resolution of $30 \mathrm{mpp}$ from the multispectral sensors of the Landsat 7 satellite and $15 \mathrm{mpp}$ from Landsat 8 . In addition to these annual low-resolution images, some high-resolution images from the WorldView-1/2/3 series and GeoEye-1 satellites are also available, but only since 2002 . These high-resolution images may vary from $2 \mathrm{mpp}$ to $0.5 \mathrm{mpp}$ depending on the location and on the proximity to the ground for the altitude view in the software.
Some Google Earth high-resolution images with an altitude view of $6 \mathrm{~km}$ above the ground were imported to the Qgis 2.8 Palmas edition software to analyze the main direction of the group of waves. The swell lines were vectorized when visible in the images. The $28 / 12 / 2002$, 10/01/2009, 26/08/2012, 04/25/2013, 04/09/2014, $06 / 20 / 2015$ and 06/12/2016 Google Earth images have a good resolution that allowed the vectorization of the group of wave directions near Boiçucanga. Using geographical north as zero degrees, it was possible to calculate the mean wave direction from the vectorized lines. The resulting line of this process is highlighted in blue in Figure 3.

\section{MORPHODYNAMIC MODELS}

By analyzing all of the data produced during the field surveys and the remote analysis of this study, it was possible to apply the classical morphodynamic models as described in Table 1.

\section{RESULTS}

The Boiçucanga beach arc (SI) is $1920 \mathrm{~m}$ long, with an embayment depth (a) of $525 \mathrm{~m}$ and a mean wave direction $(\beta)$ of $20.5^{\circ}$ in relation to the control line (Ro) that connects the two opposite sides of the headlands that surround the beach (Figure 3). By applying the Silvester 


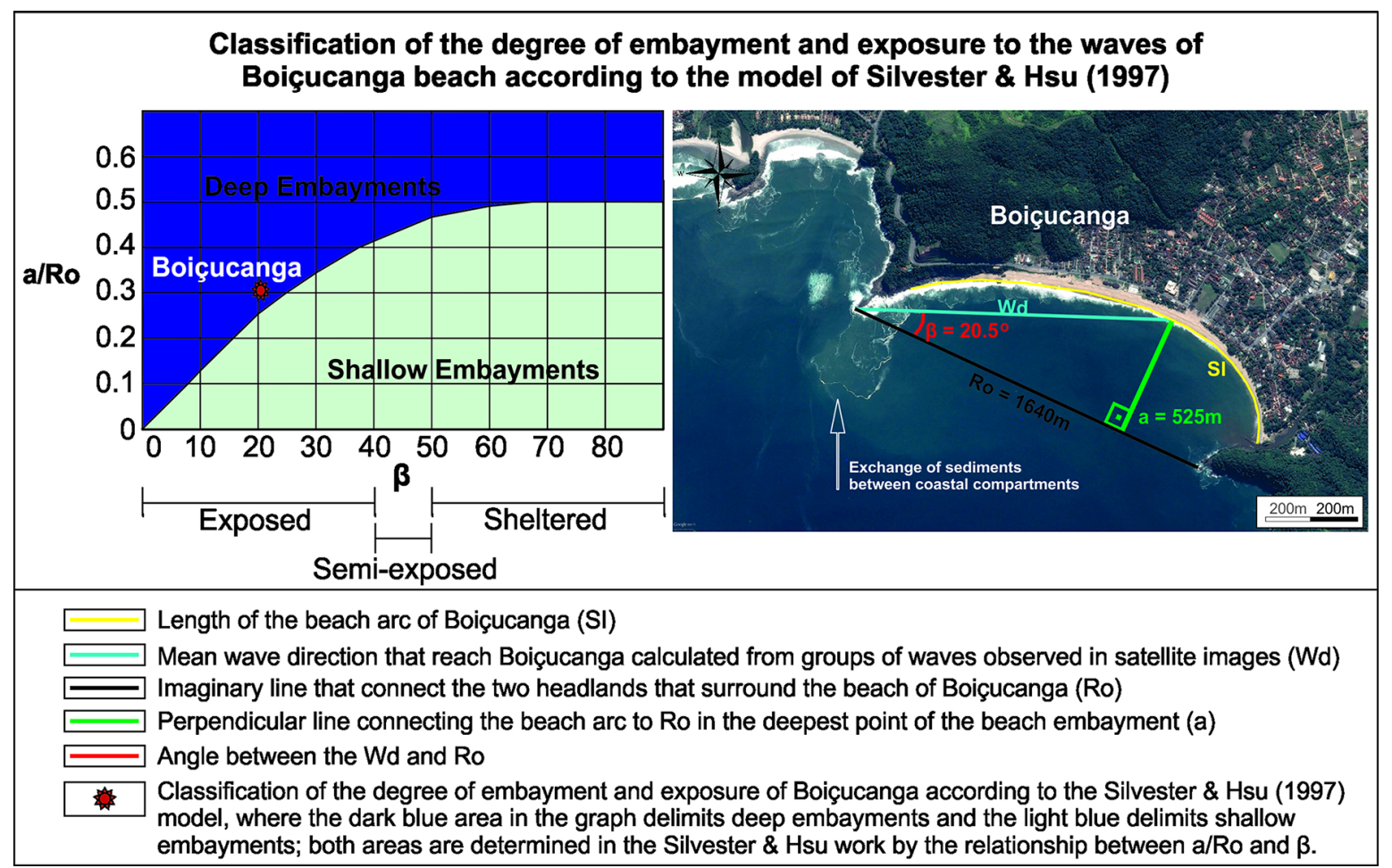

Figure 3. Classification of Boiçucanga beach regarding its level of embayment according to the Silvester and Hsu (1997) model. The image on the left of the figure shows an imaginary red line that connects the two promontories that enclose the embayed beach (Ro), a perpendicular white line that connects Ro to the farthest point of the shoreline (a), a yellow shoreline (SI) and the red angle of mean direction incidence of waves (B) relative to Ro. The graphic in the right side of the figure shows the hyperbolic curve that determine the numerical limits that define the degree of embayment or exposure as a function of a/Ro and $\beta$ values according to Silvester and Hsu (1997)

and Hsu (1997) model for embayed beaches, Boiçucanga is classified as an exposed beach in a deep embayment.

From the Google Earth image in Figure 3, it is possible to observe a very clear plume of suspended sediment that crosses the headland at the western border of Boiçucanga beach. This image was taken on $25 / 04 / 2013$, but it is not unique. The Google Earth images from 10/01/2009, 20/06/2015 and 12/06/2016 also show a suspended plume of sediments crossing the western limit of Boiçucanga. This process of sediment bypass indicates that Boiçucanga is not a closed system regarding coastal circulation cells and sediment transport. The plume of sediments also indicates the presence of well-developed rip currents, which are topographically controlled by the headlands. Six days after the Google Earth 2009 image had shown the occurrence of sediment bypass in Boiçucanga, the beach profiles sampled during the field survey on 16/01/2009 showed some very steep profile characteristics of coastal erosion after storms, especially in sectors A, B and C of the beach (yellow lines in Figure 4).
Figure 4 shows the envelope of variation of the beach profiles for the 4 sectors monitored along the 15 field surveys. The blue line with the WLAP inscription indicates the WaterLine Average Position during the surveys; this line varied among the different surveys, however, as all the field surveys were performed during the low spring tide, the average position in the graph is not far from their real position and gives a good approximation of when and how many points were collected on the beach profile below the waterline. The abscissa axis was positioned in the geographic quota zero (SAD69 datum) and the coordinate axis was moved to the position -5 as an artifice to illustrate the differences in altitude between the IBGE geodesic landmark used in this study (red circle in the figure) and the altitude of the base points of the profiles. The real horizontal distance between the geodesic mark and all four base points of the profiles are shown in Figure 2. These data ensure that the base point of the profiles did not have variations in their geographic position or in their altitude along the 15 field surveys. 
Table 1. The five classical morphodynamic models applied to this study to classify the morphodynamic characteristics of Boiçucanga beach

\begin{tabular}{|c|c|c|c|c|c|}
\hline & Name & Reference & Model & Parameters & Classification \\
\hline 1 & $\begin{array}{c}\text { The dimensionless } \\
\text { sediment fall velocity } \\
\text { parameter }\end{array}$ & Wright \& Short, 1984 & $\Omega=\mathrm{Hb} /(\mathrm{Ws} \mathrm{Tp})$ & $\begin{array}{c}\mathrm{Hb}=\text { the significant } \\
\text { wave high in the } \\
\text { breaking zone } \\
* \mathrm{Ws}=\text { the settling } \\
\text { velocity of the } \\
\text { sediments } \\
\mathrm{Tp}=\text { the incident mean } \\
\text { wave period }\end{array}$ & $\begin{array}{l}\text { reflective }(\Omega<=1) \\
\text { intermediate } \\
\quad(1<\Omega<6) \\
\text { dissipative }(\Omega>=6)\end{array}$ \\
\hline 2 & $\begin{array}{c}\text { The occurrence } \\
\text { numbers of nearshore } \\
\text { sandbars }\end{array}$ & $\begin{array}{c}\text { Short and Aagaard, } \\
1993\end{array}$ & $\mathrm{~B}^{*}=\chi \mathrm{S} / \mathrm{g} \cdot \tan \beta \mathrm{Ti}^{2}$ & $\begin{array}{c}\chi \mathrm{s}=\text { the nearshore } \\
\text { length } \\
\mathrm{g}=\text { the gravitational } \\
\text { force } \\
\tan \beta=\text { the nearshore } \\
\text { slope } \\
* *(\mathrm{Ti}) 2=\text { the period of } \\
\text { wave during storms }\end{array}$ & $\begin{array}{c}\mathrm{B}<20, \text { no sandbars } \\
20>\mathrm{B}<50,1 \text { sandbar } \\
50>\mathrm{B}<100,2 \\
\text { sandbars } \\
100>\mathrm{B}<400,3 \\
\text { sandbars }\end{array}$ \\
\hline 3 & $\begin{array}{l}\text { The relative tidal range } \\
\text { model }\end{array}$ & Masselink, 1993 & $\mathrm{RTR}=\mathrm{TR} / \mathrm{Hb}$ & $\begin{array}{c}* * * \mathrm{TR}=\text { the spring } \\
\text { tidal range }\end{array}$ & $\begin{array}{c}\mathrm{RTR}<3 \text {, wave } \\
\text { dominated } \\
3<\mathrm{RTR}<7 \text {, mixed } \\
\mathrm{RTR}>7 \text {, tide } \\
\text { dominated }\end{array}$ \\
\hline 4 & $\begin{array}{c}\text { The ratio of a bay } \\
\text { indentation }\end{array}$ & Silvester \& Hsu, 1997 & $\mathrm{a} /$ Ro---> $\beta$ & $\begin{array}{c}\mathrm{a}, \text { Ro and } \beta= \\
\text { Graphical definitions - } \\
\text { see figure } 4\end{array}$ & $\begin{array}{c}\text { Graphical limits - see } \\
\text { figure } 4\end{array}$ \\
\hline 5 & $\begin{array}{l}\text { The embayment } \\
\text { scaling parameter }\end{array}$ & $\begin{array}{c}\text { Castelle \& Coco, } 2012 \\
\text { adapted from Short \& } \\
\text { Masselink, } 1999\end{array}$ & $\delta=\mathrm{Sl} \gamma \mathrm{b} \wp / \mathrm{Hb}$ & $\begin{array}{c}\delta^{\prime}=\text { embayment } \\
\text { scaling parameter } \\
\mathrm{Sl}=\text { embayment length } \\
* * * * \gamma_{\mathrm{b}}=\text { breaking } \\
\text { parameter } \\
\beta=\text { beach surf zone } \\
\text { slope }\end{array}$ & $\begin{array}{c}\delta<8, \text { closed } \\
\text { circulation } \\
8>\delta<20, \text { transitional } \\
\text { circulation } \\
\delta>20, \text { normal } \\
\text { circulation }\end{array}$ \\
\hline
\end{tabular}

\footnotetext{
* The Ws parameter was calculated using the (Wu \& Wang, 2006) settling velocity formula
}

** The Ti was obtained from the historical series of waves in deep waters between 2008 and 2009, accessed at WaveWatchIII database of NOAA, on the website: ftp://polar.ncep.noaa.gov/pub/history/waves (last access, November 22, 2012, in the coordinates 5086400, 2740000 UTM-WGS84)

*** The TR was obtained from the tide prediction tables available online at the Brazilian Navy website: http://www.mar.mil.br/dhn/chm/boxprevisao-mare/tabuas/ (last access, September 16, 2009).

**** The $\gamma_{\mathrm{b}}$, in this study was set as 0.73 , following the Battjes and Stive, 1985 work.

The envelope of the Boiçucanga beach profiles shows that sectors A, B and C have much greater sediment mobility than sector $\mathrm{D}$. This result was already expected since sector $\mathrm{D}$ is naturally more sheltered from the direct action of the waves. The field surveys that presented the largest negative variations in the beach profiles (erosion profiles) occurred on the dates of 23/06/2008, 29/09/2008, 16/01/2009, $10 / 06 / 2009$, and 21/08/2009; with the exception of January 2009 , these were precisely the surveys that preceded the periods with a high percentage of waves coming from $135^{\circ}$ to $270^{\circ}$ with heights above $2.5 \mathrm{~m}$ in deep water. For the period of time that precedes the January survey, only $6 \%$ of that period had waves over $2.5 \mathrm{~m}$ spreading through the Boiçucanga region; however, among this $6 \%$, there were at least two events with wave heights of approximately $4 \mathrm{~m}$ in deep water, as shown in Figure 5.

Figure 5 presents a) the WW3 events of wave height over $2.5 \mathrm{~m}$ propagating from $135^{\circ}$ to $270^{\circ}$ in deep waters (black marks); b) the WW3 average of wave heights during the field surveys (red marks); c) the significant wave height taken from visual observations during the field surveys (blue marks); and d) the quadrant direction of the WW3 and observed waves (blue box). The vertical dashed red lines correspond to the time space between two monthly surveys performed, and the numbers at the top of the red lines inside the dashed red box represent the percentage of time the waves remained above $2.5 \mathrm{~m}$ in deep water between two field surveys. 
Envelope of beach profiles - Boiçucanga (Apr. 2008 - Sep. 2009)
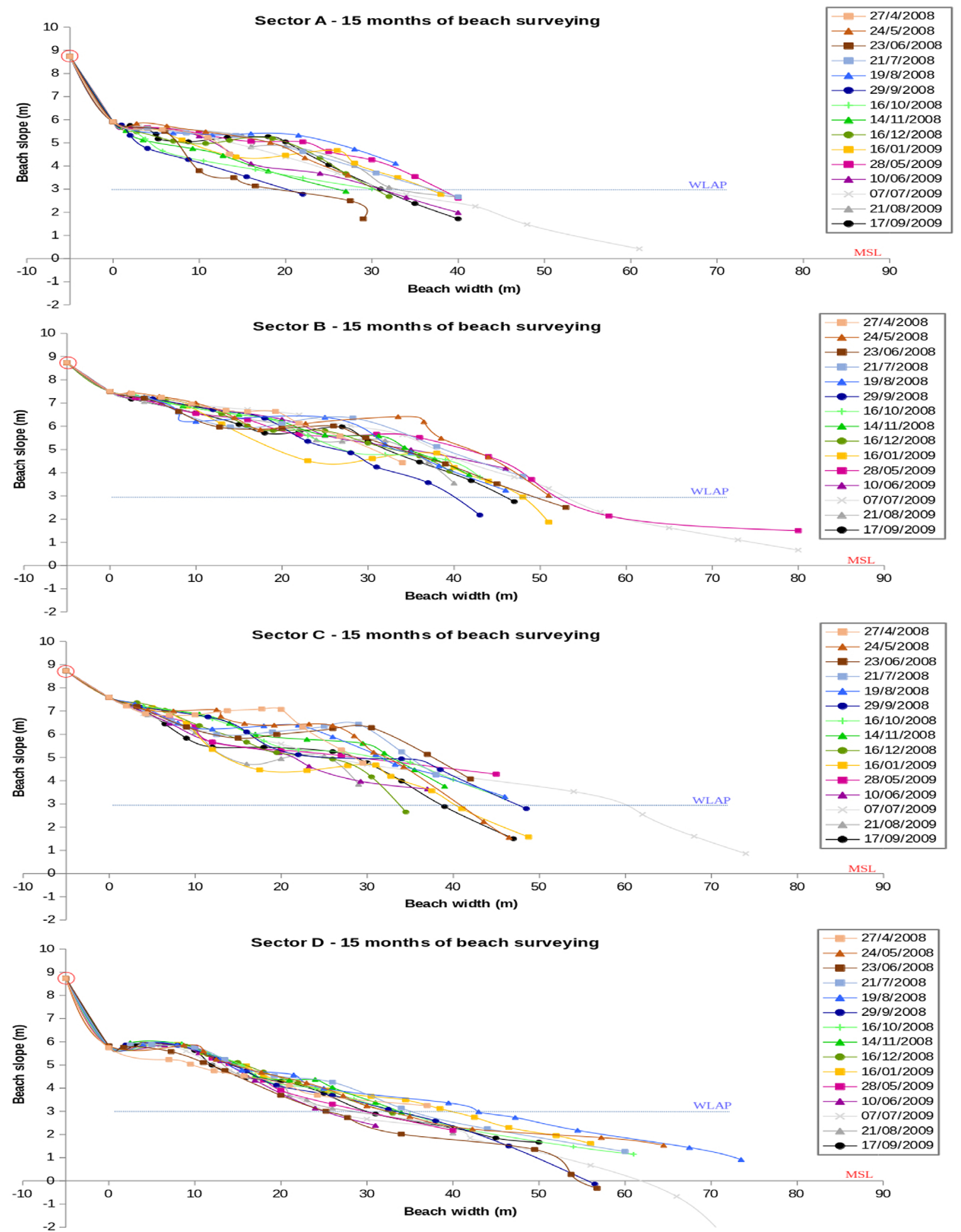

Figure 4. Boiçucanga cross-shore profile surveys (April 2008-September 2009). 


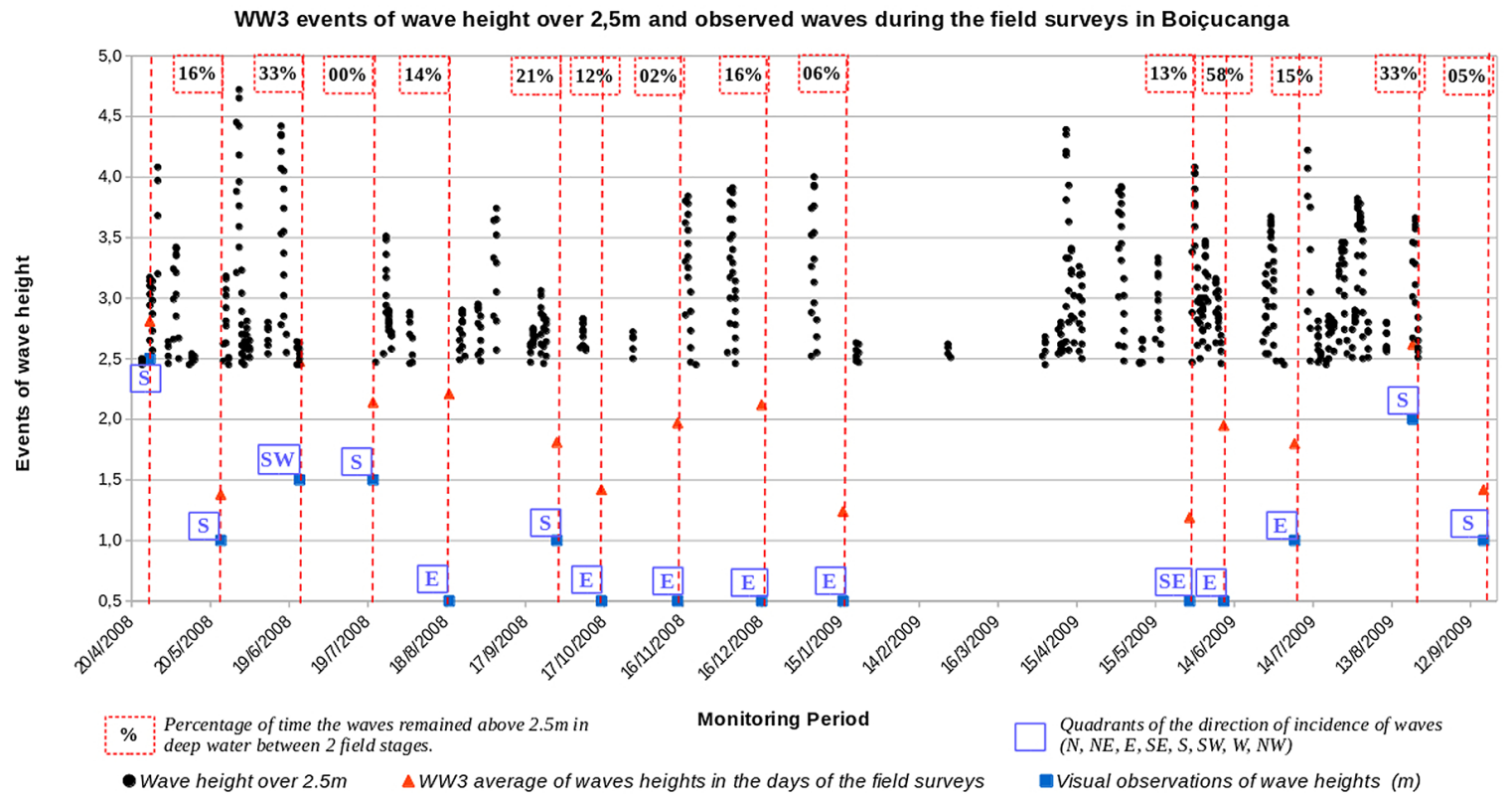

Figure 5. Events of wave height over $2.5 \mathrm{~m}$ propagating from 135 and 270 degrees in deep waters along the study site and the average height of waves during the surveyed days compiled from NOAA/WW3, and the significant wave height taken from visual observation from the wave breaking zone during the monthly surveys.

The comparison between the red and blue marks in Figure 5 shows that the waves from the $\mathrm{S}$ and $\mathrm{SE}$ quadrants have a wave height reduction on the order of $1 \mathrm{~m}$, while the waves from the SW and $\mathrm{E}$ have an average reduction on the order of $2-3 \mathrm{~m}$. Hence, the waves from $135^{\circ}$ to $202.5^{\circ}$ over $2.5 \mathrm{~m}$ in deep water may reach the study site with heights above $1.5 \mathrm{~m}$; i.e., these waves correspond to the most significant waves that promote morphological changes to the beach. The waves from the E and SW are attenuated by the processes of refraction and diffraction due to the position of the Boiçucanga coastline and the islands that surround the beach. A large negative variation of the profiles in sector D is shown in the June 2008 survey, when the waves were reaching Boiçucanga mainly from the SW (brown line with squares in sector D - Figure 4).

The period between the June 2008 and July 2008 surveys experienced a lack of waves over $2.5 \mathrm{~m}$, and the beach morphology underwent its main recovery time process during this same period, as shown by the comparison between the brown and light blue lines in all sectors of Figure 4 and by the sediment volume variation presented in Table 2. Table 2 shows that in the balance sheets for 12 months of surveys, sectors B, C and $\mathrm{D}$ showed tendencies of sediment volume loss, while sector A showed a very slight tendency of volume gain. However, for the 15 months of surveys, all four sectors presented a small tendency of sediment loss.
The grain size analysis, also from Table 2, shows that sectors $\mathrm{A}, \mathrm{B}$ and $\mathrm{C}$ have a higher predominance of coarse sand. Sector A has an average grain size of approximately $0.54 \mathrm{~mm}$, sector $\mathrm{B}, 0.63 \mathrm{~mm}$ and sector $\mathrm{C}, 0.59 \mathrm{~mm}$. On the other hand, sector $\mathrm{D}$ has predominantly fine sediments with an average size of approximately $0.23 \mathrm{~mm}$. Despite differing grain sizes, the average beach slope $(\beta)$ for all profiles are very similar, at approximately 5 degrees, which indicates that the sediment grain size is not the main factor that governs the beach slope.

The Folk and Ward (1957) cumulative logarithmic graph of the granulometric measurements of the sediment samples is shown in Figure 6. The Folk and Ward (1957) analysis shows that sectors $\mathrm{A}, \mathrm{B}$, and $\mathrm{C}$ are predominantly composed of well-sorted sediments, with a symmetrical and mesokurtic distribution and with a greater tendency for a leptokurtic distribution. Conversely, sector D has a much higher variation of characteristics for the sediment analyses. From a total of 14 samples, 4 were classified as moderately sorted, 7 as moderately well-sorted and 3 as well-sorted. The moderately sorted samples were classified as platykurtic, the moderately well-sorted samples were classified mainly as mesokurtic, and 2 of the 3 well-sorted samples were classified as leptokurtic. Almost all samples analyzed in sector D had a high tendency towards a coarse sediment skewness distribution. To complement the 


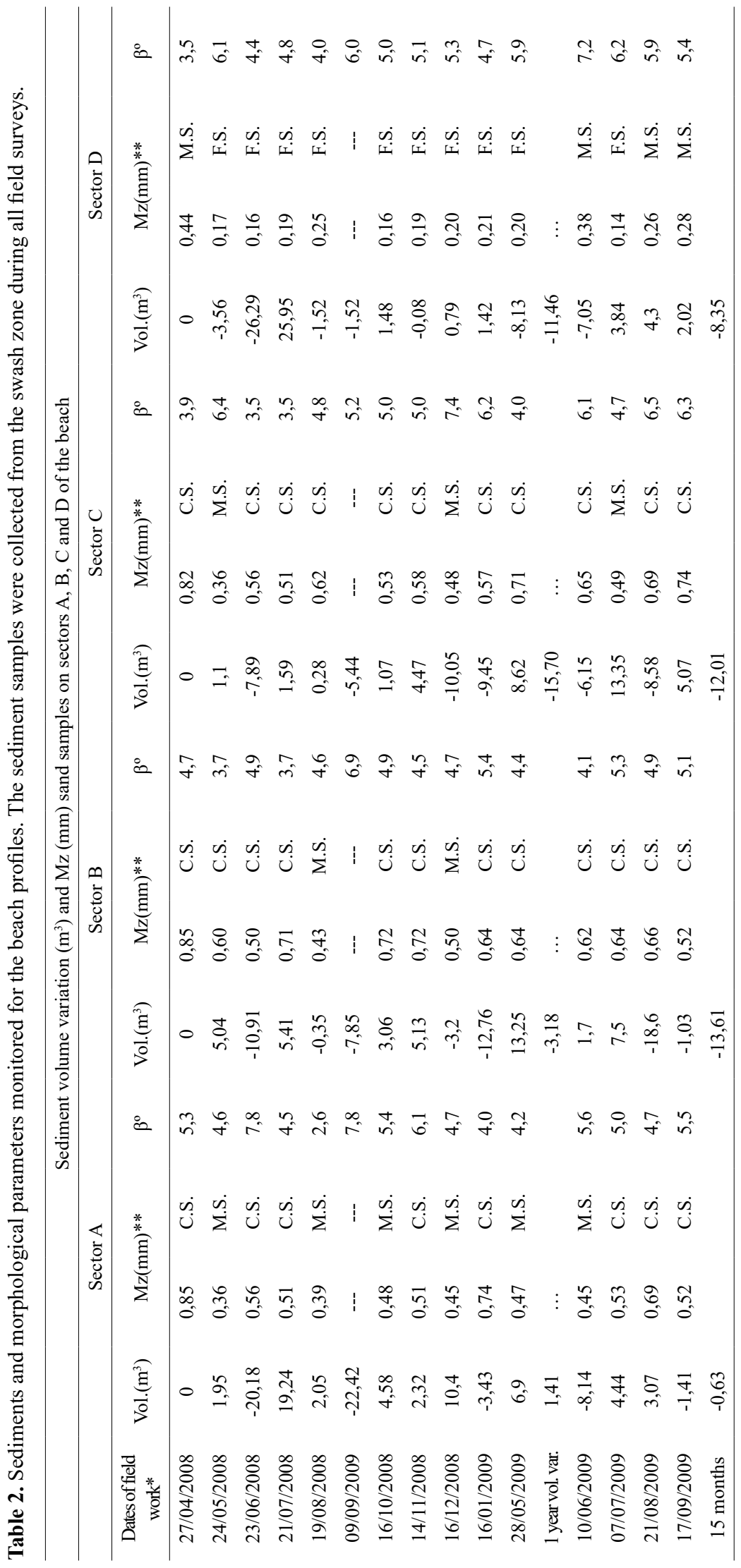




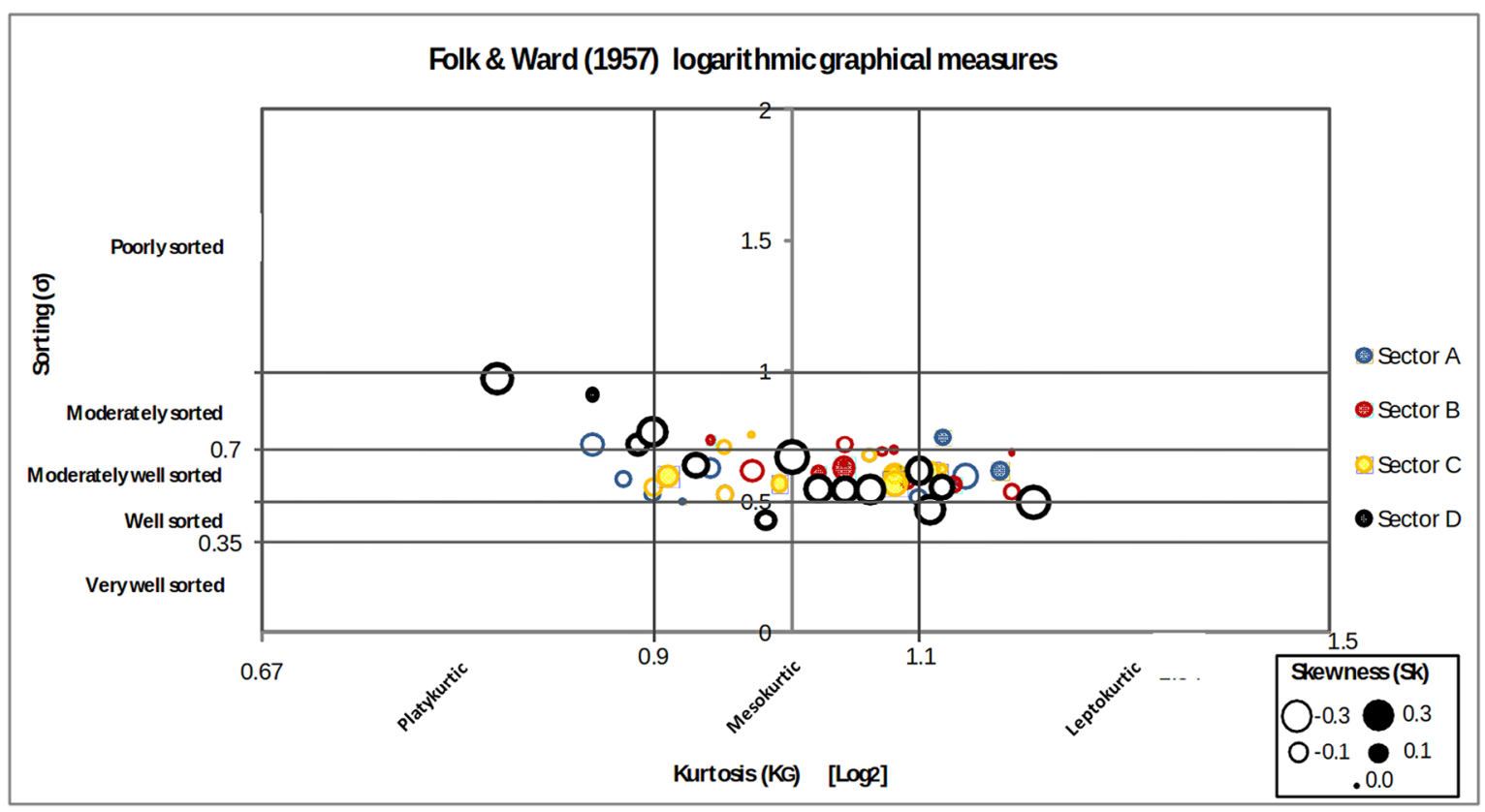

Figure 6. Folk \& Ward (1957) logarithmic graphical measures: sorting, kurtosis and skewness for sectors A, B, C and D of the Boiçucanga beach.

sediment analyses, 150 grains of quartz were extracted from the $0.250 \mathrm{~mm}$ sieved sediment samples to perform the morphoscopic analyses to better understand where these sediments were originated. Figure 7 shows the results of the morphoscopic analyses.

The morphoscopy of the quartz grains indicates that sectors $\mathrm{A}, \mathrm{B}$, and $\mathrm{C}$ have predominantly subrounded sediments, followed by rounded sediment grains with an average sphericity of approximately 0.78 . Sector D also had predominantly subrounded sediments, but there were many subangular sediments. The average sphericity in sector D is 0.78 , which is the same as that observed in the other three sectors. All the data presented above supported the calculations of the classical morphodynamic models presented in Figure 8. The four sectors of Boiçucanga beach could be classified morphodynamically in each field survey performed using the results of these models.

The results based on the morphodynamic models (Figure 8) indicate that all sectors of Boiçucanga beach are wave-dominated and have a normal circulation classification according to the modeled "embayment scaling parameter". Sectors A, B and C are predominantly reflective, progressing to intermediate profiles when subjected to high-energy wave events. Sector D is predominantly intermediate, evolving to a dissipative profile when there is an increase in wave energy. Sectors $\mathrm{A}, \mathrm{B}$ and $\mathrm{C}$ have at least one sandbar most of the time, while sector $\mathrm{D}$ does not have sandbars during the observed period.

During the field surveys, it was also possible to observe the formation of large cusps and prominent beach slopes resulting from the interaction between the incident and reflected waves with the sediments in the swash zone, especially when the beach had a more reflective than intermediate profile (Figure 9). The well-structured beach cusps shown in Figure 9 are likely originated by harmonic oscillations of the waves reflected on both the surface of the beach and the exposed rocks of the headlands. On the other hand, the beach escarpments are a consequence of the mechanical action of the waves in the swash zone, mainly when storm waves from the south quadrant reach Boiçucanga.

\section{DISCUSSION}

The Silvester and Hsu (1997) model was applied to Boiçucanga, and the existence of topographically controlled rip currents and beach cusps indicated a large influence of the surrounding headlands on the coastal circulation and approaching waves. Daly et al. (2011;2015), Razak et al. (2014), Splinter et al. (2013) and Klein and Menezes (2001) developed some modeling studies of the effects of the headlands in deeply embayed beaches; their models indicate that the development of 


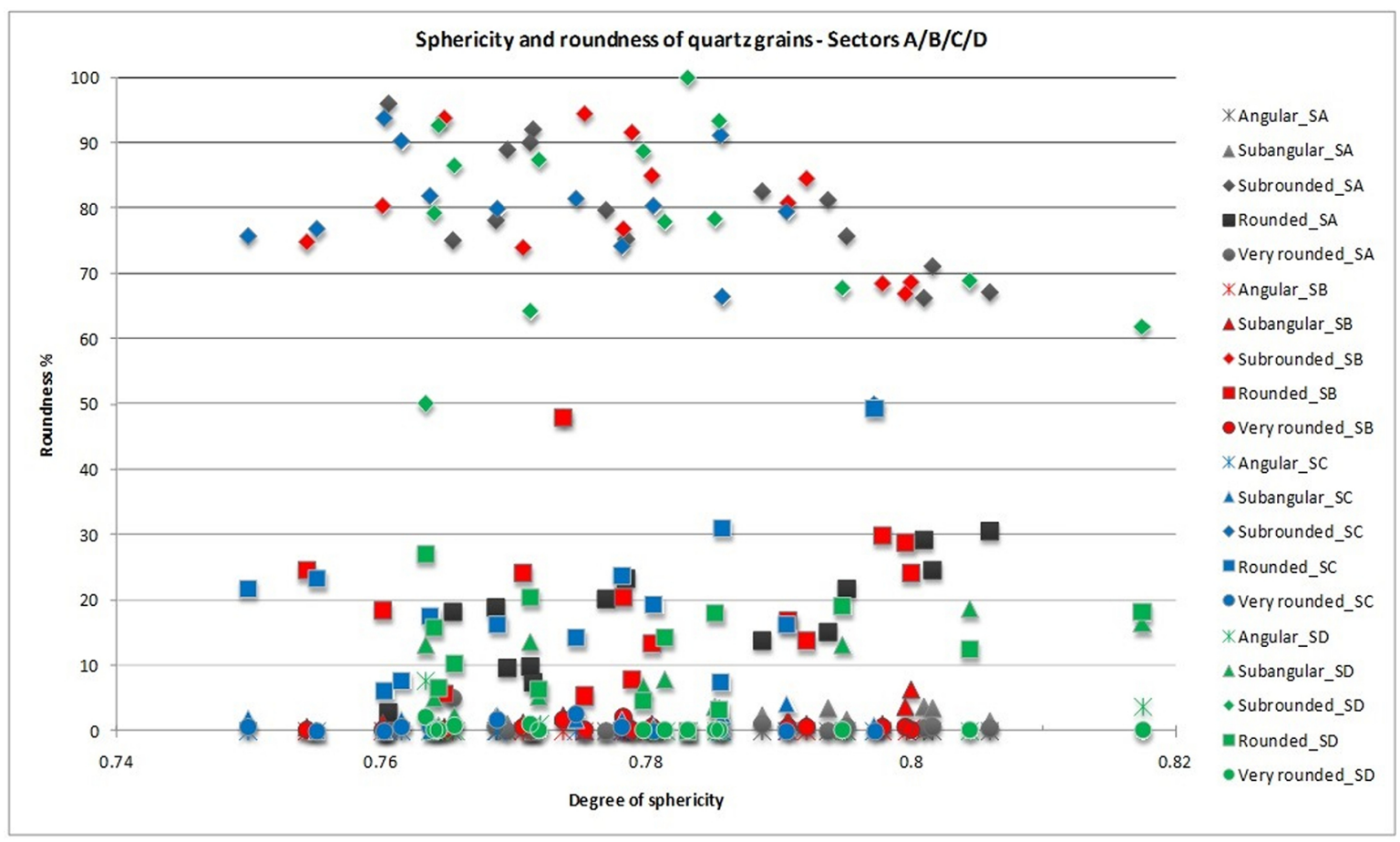

Figure 7. Morphoscopic measures: sphericity and roundness of quartz grains; fraction of $0.250 \mathrm{~mm}$ from the sieved samples.

longshore currents, rip currents and beach cusps are quite common in exposed embayed beaches.

The same authors also noted the importance of the angle of incidence of the waves for the development of longshore currents responsible for reworking the shape of the beach arc on an annual scale. The Boiçucanga sediment analysis and beach profiles have indicated a predominance of longshore currents from $\mathrm{E}$ to $\mathrm{W}$ on an annual scale. The variation of the sediment volume and grain size $(\mathrm{Mz})$ indicates a predominant transport from sector $\mathrm{C}$ to $\mathrm{A}$ on an annual scale, since there were annual losses of sediment on a larger scale in sector $\mathrm{C}$ compared to $\mathrm{B}$, while $\mathrm{A}$ had a positive balance; however, a depositional tendency of sediments that were slightly thinner than those of sectors $\mathrm{B}$ and $\mathrm{C}$ indicates that part of the sediments from sectors $\mathrm{C}$ and $\mathrm{B}$ are being transported to sector $\mathrm{A}$.

Several authors, such as Visher (1969), Nielsen (1986) and van Rijn (1984) relate the mean sediment grain size to the flow direction. The transport direction generally occurs from the most energetic areas with coarser grains to the less energetic area, characterized by thinner sediments. The less energetic area has finer grains due to loss of flow competence along the traversed trajectory.

Since Boiçucanga is not a closed system, some of the sediments transported to A are lost to the neighboring beaches because of bypass processes; the other sediments remain trapped in submerged sandbars and return to the beach face during good weather conditions. These processes could be demonstrated through the large recovery capacity of the beach profiles after events of high-energy waves on a monthly scale and the application of the Short and Aagard (1993) model - "The occurrence numbers of nearshore sandbars" - which showed that the steeper slope profiles generated after one or more events of beach erosion caused by the action of storm waves favored the development of submerged sandbars. In addition, these sandbars tend to disappear when the beach profiles recover with a smoothed slope.

Fast beach face recovery after storm events, with similar rates to those observed in Boiçucanga, were also documented by Short and Wright (1981) in southeast Australia and by Roberts et al. (2013) in Delaware - US; by contrast, Corbella and Stretch (2012) measured a period of up to two years for the full recovery of the beach profiles on the eastern coast of South Africa after extreme storms. There are several differences between the environmental features of these sites; however, wave-dominated embayed beaches with a parabolic shape and sediments composed predominantly of coarse sand, in general, appear to have a faster recovery rate (Wright et al., 1985; Larson and Kraus, 


\begin{tabular}{|c|c|c|c|c|c|c|c|c|c|}
\hline \multicolumn{10}{|c|}{ Sector A } \\
\hline & Data & \multicolumn{2}{|c|}{$\delta^{\prime}$} & \multicolumn{2}{|c|}{ RTR } & \multicolumn{2}{|r|}{$\Omega$} & \multicolumn{2}{|r|}{$B^{*}$} \\
\hline & $27 / 04 / 2008$ & 41.0 & n.c. & 0.1 & w.d. & 2.5 & intermidiate & 76.4 & 2 sandbars \\
\hline & $24 / 05 / 2008$ & 106.4 & n.c. & 0.8 & w.d. & 2.3 & intermidiate & 21.2 & 1 sandbar \\
\hline & $23 / 06 / 2008$ & 178.8 & n.c. & 1.1 & w.d. & 1.3 & intermidiate & 33.7 & 1 sandbar \\
\hline & $21 / 07 / 2008$ & 104.5 & n.c. & 1.0 & w.d. & 1.6 & intermidiate & 20.8 & 1 sandbar \\
\hline f & $19 / 08 / 2008$ & 120.9 & n.c. & 2.2 & w.d. & 0.8 & reflective & 14.1 & no sandbars \\
\hline & $29 / 09 / 2008$ & 362.1 & n.c. & 2.2 & w.d. & 0.6 & reflective & 84.4 & 2 sandbars \\
\hline & $16 / 10 / 2008$ & 246.8 & n.c. & 1.8 & w.d. & 0.8 & reflective & 23.3 & 1 sandbar \\
\hline & $14 / 11 / 2008$ & 279.9 & n.c. & 1.4 & w.d. & 0.6 & reflective & 43.5 & 1 sandbar \\
\hline & $16 / 12 / 2008$ & 215.5 & n.c. & 0.8 & w.d. & 0.7 & reflective & 33.5 & 1 sandbar \\
\hline & $16 / 01 / 2009$ & 183.7 & n.c. & 1.0 & w.d. & 0.5 & reflective & 11.6 & no sandbars \\
\hline & $28 / 05 / 2009$ & 191.8 & n.c. & 1.4 & w.d. & 0.7 & reflective & 37.2 & 1 sandbar \\
\hline & $10 / 06 / 2009$ & 128.8 & n.c. & 1.0 & w.d. & 1.8 & intermidiate & 38.4 & 1 sandbar \\
\hline & $07 / 07 / 2009$ & 230.5 & n.c. & 2.4 & w.d. & 0.6 & reflective & 17.9 & no sandbars \\
\hline & $21 / 08 / 2009$ & 54.5 & n.c. & 0.7 & w.d. & 3.3 & intermidiate & 24.4 & 1 sandbar \\
\hline & $17 / 09 / 2009$ & 126.7 & n.c. & 1.2 & w.d. & 1.6 & intermidiate & 37.8 & 1 sandbar \\
\hline \multicolumn{10}{|c|}{ Sector B } \\
\hline & Data & \multicolumn{2}{|l|}{$\delta^{\prime}$} & \multicolumn{2}{|c|}{$R T R$} & \multicolumn{2}{|r|}{$\Omega$} & \multicolumn{2}{|r|}{$B^{*}$} \\
\hline & $27 / 04 / 2008$ & 36.3 & n.c. & 0.1 & w.d. & 3.3 & intermidiate & 50.8 & 2 sandbars \\
\hline & $24 / 05 / 2008$ & 85.8 & n.c. & 0.8 & w.d. & 1.9 & intermidiate & 12.8 & no sandbars \\
\hline & $23 / 06 / 2008$ & 113.3 & n.c. & 1.1 & w.d. & 2.0 & intermidiate & 14.2 & no sandbars \\
\hline & $21 / 07 / 2008$ & 85.1 & n.c. & 1.0 & w.d. & 1.6 & intermidiate & 12.7 & no sandbars \\
\hline & $19 / 08 / 2008$ & 210.8 & n.c. & 2.2 & w.d. & 1.1 & intermidiate & 24.6 & 1 sandbar \\
\hline & $29 / 09 / 2008$ & 318.3 & n.c. & 2.2 & w.d. & 0.9 & reflective & 49.4 & 1 sandbar \\
\hline & $16 / 10 / 2008$ & 224.2 & n.c. & 1.8 & w.d. & 0.7 & reflective & 21.2 & 1 sandbar \\
\hline & $14 / 11 / 2008$ & 206.3 & n.c. & 1.4 & w.d. & 0.6 & reflective & 24.0 & 1 sandbar \\
\hline & $16 / 12 / 2008$ & 217.9 & n.c. & 0.8 & w.d. & 0.9 & reflective & 25.4 & 1 sandbar \\
\hline & $16 / 01 / 2009$ & 247.8 & n.c. & 1.0 & w.d. & 0.8 & reflective & 15.6 & no sandbars \\
\hline & $28 / 05 / 2009$ & 202.4 & n.c. & 1.4 & w.d. & 0.7 & reflective & 31.4 & 1 sandbar \\
\hline & $10 / 06 / 2009$ & 94.7 & n.c. & 1.0 & w.d. & 1.8 & intermidiate & 28.3 & 1 sandbar \\
\hline & $07 / 07 / 2009$ & 244.9 & n.c. & 2.4 & w.d. & 0.7 & reflective & 19.0 & no sandbars \\
\hline & $21 / 08 / 2009$ & 55.8 & n.c. & 0.7 & w.d. & 4.6 & intermidiate & 25.0 & 1 sandbar \\
\hline & $17 / 09 / 2009$ & 118.1 & n.c. & 1.2 & w.d. & 2.1 & intermidiate & 35.2 & 1 sandbar \\
\hline & Sector & & & & & & & & \\
\hline & Data & $\delta^{\prime}$ & & $R$ & $T R$ & & $\Omega$ & & $B^{*}$ \\
\hline & $27 / 04 / 2008$ & 29.5 & n.c. & 0.1 & w.d. & 3.4 & intermidiate & 41.3 & 1 sandbar \\
\hline & $24 / 05 / 2008$ & 147.6 & n.c. & 0.8 & w.d. & 3.3 & intermidiate & 22.0 & 1 sandbar \\
\hline & $23 / 06 / 2008$ & 80.7 & n.c. & 1.1 & w.d. & 1.8 & intermidiate & 10.1 & no sandbars \\
\hline & $21 / 07 / 2008$ & 79.2 & n.c. & 1.0 & w.d. & 2.2 & intermidiate & 11.8 & no sandbars \\
\hline & $19 / 08 / 2008$ & 221.8 & n.c. & 2.2 & w.d. & 0.7 & reflective & 17.2 & no sandbars \\
\hline & $29 / 09 / 2008$ & 237.3 & n.c. & 2.2 & w.d. & 0.9 & reflective & 36.9 & 1 sandbar \\
\hline- & $16 / 10 / 2008$ & 232.1 & n.c. & 1.8 & w.d. & 0.9 & reflective & 14.6 & no sandbars \\
\hline & $14 / 11 / 2008$ & 228.6 & n.c. & 1.4 & w.d. & 0.8 & reflective & 26.6 & 1 sandbar \\
\hline & $16 / 12 / 2008$ & 340.1 & n.c. & 0.8 & w.d. & 0.9 & reflective & 39.6 & 1 sandbar \\
\hline & $16 / 01 / 2009$ & 284.3 & n.c. & 1.0 & w.d. & 0.9 & reflective & 8.9 & no sandbars \\
\hline & $28 / 05 / 2009$ & 181.9 & n.c. & 1.4 & w.d. & 0.6 & reflective & 28.2 & 1 sandbar \\
\hline & $10 / 06 / 2009$ & 140.2 & n.c. & 1.0 & w.d. & 1.7 & intermidiate & 41.8 & 1 sandbar \\
\hline & $07 / 07 / 2009$ & 216.5 & n.c. & 2.4 & w.d. & 0.9 & reflective & 16.8 & no sandbars \\
\hline & $21 / 08 / 2009$ & 75.0 & n.c. & 0.7 & w.d. & 4.4 & intermidiate & 25.2 & 1 sandbar \\
\hline & $17 / 09 / 2009$ & 144.3 & n.c. & 1.2 & w.d. & 1.6 & intermidiate & 43.0 & 1 sandbar \\
\hline & Sector & & & & & & & & \\
\hline & Data & $\delta$ & & & $T R$ & & $\Omega$ & & $B^{*}$ \\
\hline & $27 / 04 / 2008$ & 81.2 & n.c. & 0.3 & w.d. & 2.1 & intermidiate & 31.5 & 1 sandbar \\
\hline & $24 / 05 / 2008$ & 281.7 & n.c. & 1.6 & w.d. & 5.0 & intermidiate & 14.0 & no sandbars \\
\hline & $23 / 06 / 2008$ & 203.4 & n.c. & 2.2 & w.d. & 4.9 & intermidiate & 6.4 & no sandbars \\
\hline & $21 / 07 / 2008$ & 221.0 & n.c. & 2.0 & w.d. & 4.2 & intermidiate & 11.0 & no sandbars \\
\hline & 19/08/2008 & 183.7 & n.c. & 2.2 & w.d. & 2.1 & intermidiate & 7.1 & no sandbars \\
\hline tsy & $29 / 09 / 2008$ & 277.5 & n.c. & 2.2 & w.d. & 3.1 & intermidiate & 21.6 & 1 sandbar \\
\hline$\pi$ & $16 / 10 / 2008$ & 231.5 & n.c. & 1.8 & w.d. & 5.0 & intermidiate & 7.3 & no sandbars \\
\hline & $14 / 11 / 2008$ & 235.7 & n.c. & 1.4 & w.d. & 3.3 & intermidiate & 18.3 & no sandbars \\
\hline & $16 / 12 / 2008$ & 246.0 & n.c. & 0.8 & w.d. & 3.2 & intermidiate & 19.1 & no sandbars \\
\hline ह. & $16 / 01 / 2009$ & 214.7 & n.c. & 1.0 & w.d. & 3.1 & intermidiate & 6.8 & no sandbars \\
\hline$==$ & $28 / 05 / 2009$ & 273.8 & n.c. & 1.4 & w.d. & 2.9 & intermidiate & 31.9 & 1 sandbar \\
\hline & $10 / 06 / 2009$ & 331.9 & n.c. & 2.0 & w.d. & 1.5 & intermidiate & 33.0 & 1 sandbar \\
\hline$\infty$ & 07/07/2009 & 286.2 & n.c. & 2.4 & w.d. & 5.8 & intermidiate & 11.1 & no sandbars \\
\hline & $21 / 08 / 2009$ & 136.4 & n.c. & 1.3 & w.d. & 6.7 & dissipative & 19.1 & no sandbars \\
\hline & $17 / 09 / 2009$ & 249.1 & n.c. & 2.4 & w.d. & 2.3 & intermidiate & 12.4 & no sandbars \\
\hline
\end{tabular}

n.c. $=$ normal circulation

w.d. = wave dominated

Figure 8. The results of the applications of the classical morphodynamic models for the sectors A, B, C and D of Boiçucanga beach. 


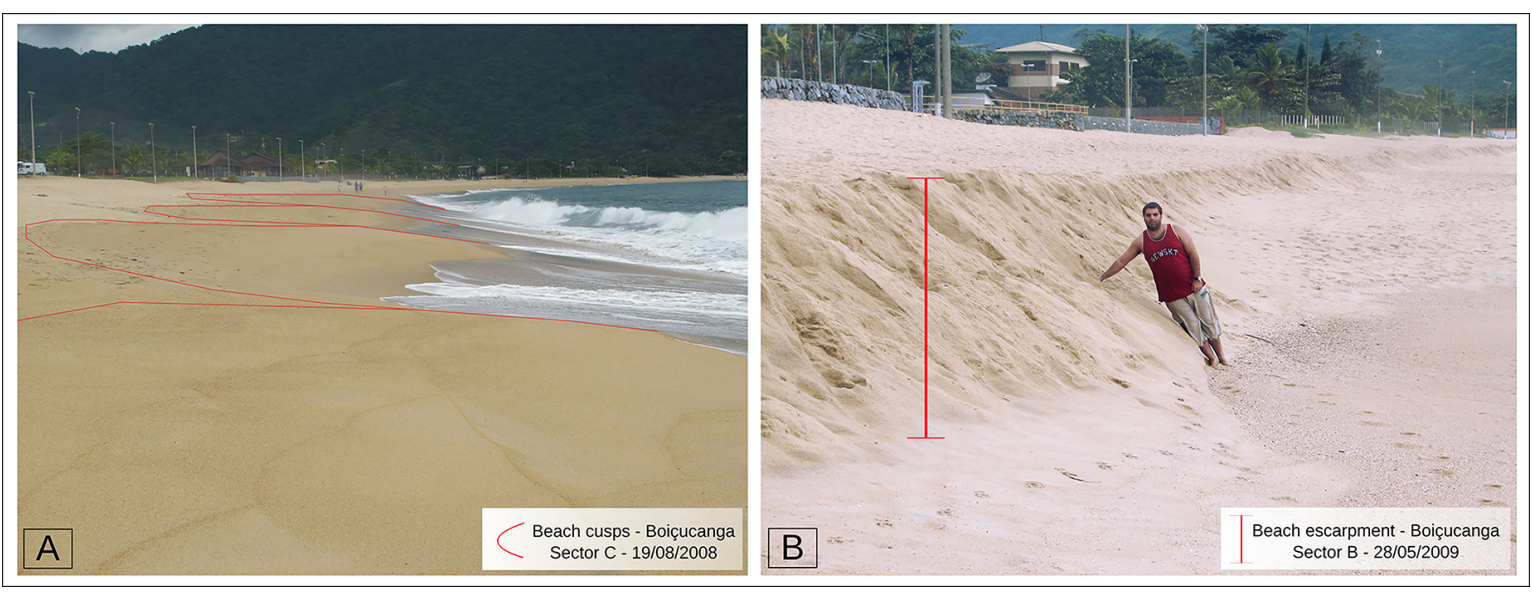

Figure 9. Beach cusps and escarpments photographed in Boiçucanga during the field surveys.

1995; Miller and Dean, 2004; Davidson and Turner, 2009; Yates et al., 2009; Davidson et al., 2010).

The substantial beach recovery rates after storms have also indicated a predominance of cross-shore sediment transport on a short time scale (months), while there is an increase in the longshore sediment transport influence on the morphological shape of the beach on an annual time frame. It is well known that both longshore and crossshore sediment transport drive changes in the shoreline position and in the beach profiles; however, the longshore sediment transport generally occurs over decadal or annual time frames, while cross-shore transport often occurs over time frames of hours, days, weeks and months (Clarke and Eliot, 1988; Davidson and Turner, 2009; Davidson et al., 2010; Hansen and Barnard, 2010; Yates et al., 2009; Splinter et al., 2013).

The cross-shore sediment transport is responsible for developing some very steep profiles on the beach face; however, the results from the sediment sample analyses indicated that the overall average beach slope $(\beta)$ of all profiles are quite similar - at approximately 5 degrees, even for sector $\mathrm{D}$, which has an average grain size considerably lower in relation to sectors A, B and C. These observations contradict some previous studies, such as Kemp and Plinston (1968), Dalrymple and Thompson (1977) and Sunamura (1984), who consider the grain size to be the most important factor that controls the slope of the beach. This contradiction may indicate that the geological heritage associated with the framework where the sediment is deposited can also be an important factor in defining the beach slope. Tessler and Goya (2005) and Klein et al. (2005) highlight the importance of the geological inheritance in shaping the current profile of embayed beaches that are surrounded by granite hills along the Brazilian coast.

The Folk and Ward (1957) sorting, kurtosis and skewness analyses of sediments for sectors A, B and C are similar - all three sectors have a large potential for sediment transport, which can be inferred from the wellsorted and predominant leptokurtic results. On the other hand, the kurtosis values for sector D indicate that most of the time this sector behaves similar to a depositional area (platykurtic), changing its behavior to a sediment transport area (leptokurtic) when it is under the influence of highenergy waves from the S and SW directions (Figure 5).

The morphoscopy differences between sectors A, B and $\mathrm{C}$ in relation to sector $\mathrm{D}$ is in accordance with the analyses of Folk and Ward (1957), indicating 2 different energetic compartments in Boiçucanga. Therefore, the variations in the percentage of rounded sediments indicates three different hydrodynamic signatures in Boiçucanga, varying from the most energetic areas sectors A, B and C - to a less energetic area - sector D. Beal and Shepard (1956), Kuenen (1964), Siegle and Calliari (2008) and Roberts et al. (2013) performed studies using granulometry and/or morphoscopy data to compare different coastal environments. In most of these studies, similar to Boiçucanga, the variations in degrees of roundness and sphericity were much more related to the hydrodynamic sorting of sand particles, as a function of the environmental energy, than to the abrasion process during sediment transport from the origin to the depositional area.

Finally, the classical models applied to the four sectors of the beach were successful since they identified the waves as the main modeling force in the Boiçucanga environment. They indicated the occurrence of normal 
circulation, that is, without restraints or confinements, and classified sectors $\mathrm{A}, \mathrm{B}$ and $\mathrm{C}$ as predominantly reflective, differently from sector $\mathrm{D}$, which is predominantly intermediate with a dissipative tendency, thus identifying two different hydrodynamic signatures over the beach arc. Different morphodynamic behaviors at the same beach arch of the embayed beaches dominated by waves are widely cited in the literature; Wright and Short (1984) have observed two different beach compartments at Collaroy beach, New South Wales, Australia, Scott et al. (2011) described different morphodynamic signatures at Porthleven Cornwall, England, Muehe (1998) also observed two different signatures at Massamba, Rio de Janeiro, Brazil and Klein and Menezes (2001) at Taquaras, Santa Catarina, Brazil.

\section{CONCLUSIONS}

Boiçucanga was largely influenced by the geological inheritance due to its limited sediment accommodation space and the influence of the surrounding headlands on the coastal circulation and approaching waves. The position of the headlands and the islands that surround the beach have provided a more sheltered area from the direct incidence of waves in sector $\mathrm{D}$, which consequently presents a lower morphological variation on a monthly scale and a finer granulometry, while sectors A, B and C are more energetic, having coarser sediments and a larger morphological variation on a monthly scale.

The waves are the main modeling force of the beach profile in Boiçucanga, and they are responsible for developing predominantly cross-shore sediment transport on a short time scale, but there is an increasing influence of longshore transport on an annual time scale. The longshore sediment transport in Boiçucanga appears to flow predominantly from east to west on an annual scale.

Further studies in the region include the application of a wave propagation numerical model in order to propagate waves onshore. Such information will provide a more quantitative approach to the wave data parameters that govern the cross- and longshore sediment transport, aiding in the assessment of beach rotation and to quantify the amount of sediment being exchanged between neighboring beaches.

\section{ACKNOWLEDGMENTS}

The authors would like to thank the Foundation for Studies and Water Research - FUNDESPA, the
Department of Environmental Impact Assessment DAIA, São Sebastião City Hall, the USP students Marcelo Gagliardi, Alynne Affonso and Juliana Rocha Menegatti, and Professors Jarrod Bryant and Heather Hargas for all the support offered during this work. We would also like to thank the two anonymous reviewers for their comments that improved our manuscript. Eduardo Siegle is a $\mathrm{CNPq}$ research fellow.

\section{REFERENCES}

ALMEIDA, F. F. M. \& CARNEIRO, C. D. R. 1998. Origem e Evolução da Serra do Mar. Revista Brasileira de Geociências, 28, 135-150.

BEAL, M. A. \& SHEPARD, F. P. 1956. A Use of Roundness to Determine Depositional Environments. Journal of Sedimentary Research, 26, 46-60.

CASTElle, B. \& COCO, G. 2012. The Morphodynamics of Rip Channels on Embayed Beaches. Continental Shelf Research, 43, 10-23.

CLARKE, D. J. \& ELIOT, I. G. 1988. Low-frequency changes of sediment volume on the beachface at Warilla Beach, New South Wales, 1975-1985. Marine Geology, 79, 189-211.

CORBELLA, S. \& STRETCH, D. D. 2012. Shoreline recovery from storms on the east coast of Southern Africa. Natural Hazards and Earth System Sciences, 12, 11-22.

DAI, Z. J., LIU, J. T., LEI, Y. P. \& ZHANG, X. L. 2010. Patterns of sediment transport pathways on a headland bay beach - Nanwan Beach, South China: A case study. Journal of Coastal Research, 26, 1096-1103.

DALRYMPLE, R. A., \& THOMPSON, W. W. 1977. Study of Equilibrium Profiles. Fifteenth International Conference on Coastal Engineering, American Society of Civil Engineers, 1277-1296.

DALY, C. J., BRYAN, K. R., ROELVINK, J. A., KLEIN, A. H. F., HEBBELN, D. \& WINTER, C. 2011. Morphodynamics of Embayed Beaches: The Effect of Wave Conditions. Journal of Coastal Research, 64, 1003-1007.

DALY, C. J., WINTER, C. \& BRYAN, K. R. 2015. On the Morphological Development of Embayed Beaches. Geomorphology, 248, 252-263.

DAVIDSON, M. A. \& TURNER, I. L. 2009. Behavioral template beach profile model for predicting seasonal to interannual shoreline evolution. Journal of Geophysical Research, 114, F01020.

DAVIDSON, M. A., LEWIS, R. P. \& TURNER, I. L. 2010. Forecasting seasonal to multi-year shore-line change. Coastal Engineering, 57, 620-629.

DEHOUCK, A., DUPUIS, H. \& SÉNÉCHAL, N. 2009. Pocket beach hydrodynamics: The example of four macrotidal beaches, Brittany, France. Journal of Marine Geology, 266, $1-17$.

FOLK, R. L. \& WARD, W. C. 1957. A Study in the Significance of Grain-Size Parameters. Journal of Sedimentary Research, 27, 3-26.

HANSEN, J. E. \& BARNARD, P. L. 2010. Sub-weekly to interannual variability of a high-energy shoreline. Coastal Engineering, 57, 959-972. 
IPT (Instituto de Pesquisas Tecnológicas). 2000. Diagnóstico da situação atual dos Recursos Hídricos da Unidade de Gerenciamento dos Recursos Hídricos do Litoral Norte. São Paulo: Nota Técnica IPT - Relatório final N 46172, 12.

KEMP, P. H., \& PLINSTON, D. T. 1968. Beaches produced by waves of low phase difference. Journal of the Hydraulics Division, 94, 1183-1195.

KLEIN, A. H. F. \& MENEZES, J. T. 2001. Beach Morphodynamics and Profile Sequence for a Headland Bay Coast. Journal of Coastal Research, 17, 812-835.

KLEIN, A. H. F., BENEDET FILHO, L. \& SCHUMACHER, D. H. 2002. Short-term beach rotation processes in distinct headland bay beach systems. Journal of Coastal Research, $18,442-458$.

KLEIN, A. H. F., SILVA, G. M., FERREIRA, O. \& DIAS, J. A. 2005. Beach Sediment Distribution for a Headland Bay Coast. Journal of Coastal Research, 42, 285-293.

KUENEN, P. H. 1964. Experimental Abrasion: 6. Surf Action. Sedimentology, 3, 29-43.

LARSON, M. \& KRAUS, N. C. 1995. Prediction of cross-shore sediment transport at different spatial and temporal scales. Marine Geology, 126, 111-127.

MARTINS, C. C., MAHIQUES, M. M. \& DIAS, J. M. A. 2010. Daily morphological changes determined by high-energy events on an embayed beach: a qualitative model. Earth Surface Processes and Landforms, 35, 487-495.

MASSELINK, G. \& SHORT, A. D. 1993. The effect of tide range on beach morphodynamics and morphology: a conceptual beach model. Journal of Coastal Research, 9, 785-800.

MILLER, J. K. \& DEAN, R. G. 2004. A simple new shoreline change model. Coastal Engineering, 51, 531-556.

MIRANDA, L. B, B. M. CASTRO, B. M., \& KJERFVE, B. 2002. Princípios de Oceanografia Física de estuários, São Paulo, Editora da Universidade de São Paulo - EDUSP.

MUEHE, D. 1996. Geomorfologia Costeira. In: CUNHA, S. B. \& GUERRA, A. J. T. (eds.) Geomorfologia: exercícios, técnicas e aplicações. Rio de Janeiro, Bertrand Brasil. p. 191238.

MUEHE, D. 1998. Estado morfodinâmico praial no instante da observação: uma alternativa de identificação. Brazilian Journal of Oceanography, 46, 157-169.

MUEHE, D. (org.) 2006. Erosão e Progradação no Litoral Brasileiro, Brasília, Ministério do Meio Ambiente.

MUEHE, D. 2005. Aspectos gerais da erosão costeira no Brasil. Mercator, v. 4, n.7.

MULLER, G. 1967. Methods in sedimentary petrology. Section in: Degree of roundness according to Russel-Taylor-Pettijohn (after Schneiderhohn). New York, Hafner Publishing Company. 100-101.

NIELSEN, P. 1986. Suspended sediment concentrations under waves. Coastal Engineering, 10, 23-31.

PIANCA, C., MAZZINI, P. L. F. \& SIEGLE, E. 2010. Brazilian off shore wave climate based on nww3 reanalysis. Brazilian Journal of Oceanography, 58, 53-70.

PRICE, T. D. \& RUESSINK, B. G. 2011. State dynamics of a double sandbar system. Continental Shelf Research, 31, 659674.
RAZAK, M. S. A., DASTGHEIB, A., SURYADI, F. X. \& ROELVINK, D. 2014. Headland structural impacts on surf zone current circulations. Journal of Coastal Research, 70, 65-71.

RITTENHOUSE, G. 1943. A visual method of estimating twodimensional sphericity. Journal of Sedimentary Petrology, $13,79-81$.

ROBERTS, T. M., WANG, P. \& PULEO, J. A. 2013. Stormdriven cyclic beach morphodynamics of a mixed sand and gravel beach along the Mid-Atlantic Coast, USA. Marine Geology, 346, 403-421.

ROLIM, G. S., CAMARGO, M. B. P., LANIA, D. G., \& MORAES J. F. L. 2007. Classificação climática de Köppen e de Thornthwaite e sua aplicabilidade na determinação de zonas agroclimáticas para o estado de São Paulo. Bragantia, $66,711-720$

SANT'ANNA NETO, J. L. 2005. Decálogo da Climatologia do Sudeste Brasileiro. Revista Brasileira de Geomorfologia, 1, 43-60.

SCOTT, T., MASSELINK, G., \& RUSSEL, P. 2011. Morphodynamic characteristics and classification of beaches in England and Wales. Marine Geology, 286, 1-20.

SHORT, A. D. 1999a. Handbook of Beach and Shoreface Morphodynamics, Chichester, John Wiley \& Sons.

SHORT, A. D. \& MASSELINK, G. 1999b. Embayed and structurally controlled beaches. In: Short, A. D. (eds.) Handbook of Beach and Shoreface Morphodynamics. Chichester: John Wiley \& Sons. 379 p.

SHORT, A. D. \& AAGAARD, T. 1993. Single and multi-bar beach change models. Journal of Coastal Research, 15, 141157.

SHORT, A. D., \& JACKSON, D. W. T. 2013. Beach Morphodynamics. In: SHRODER, J. F. (ed.) Treatise on Geomorphology, San Diego: Academic Press, p. 106-129.

SHORT, A. D., \& WRIGHT, L. D. 1981. Beach Systems of the Sydney Region. Australian Geographer, 15, 8-16.

SIEGLE, E., \& CALLIARI, L. J. 2008. High-energy Events and Short-term Changes in Superficial Beach Sediments. Brazilian Journal of Oceanography, 56, 149-152.

SILVEIRA, J. D. 1964. Morfologia do litoral. In: AZEVEDO, H (ed.) Brasil: A Terra e o Homem, (Vol I: As bases fisicas). São Paulo: Companhia Educacional Nacional, p. 253-305.

SILVEIRA, L. F., KLEIN, A. H. F. \& TESSLER, M. G. 2010. Headland-Bay beach planform stability of Santa Catarina State and of the Northern Coast of São Paulo State. Brazilian Journal of Oceanography, 58, 101-122.

SILVESTER, R. \& HSU, J. R. C. 1997. Coastal Stabilization. In: Advanced Series on Ocean Engineering. Singapore: World Scientific Publishing.

SPLINTER, K. D., TURNER, I. L. \& DAVIDSON, M. A. 2013. How much data is enough? The importance of morphological sampling interval and duration for calibration of empirical shoreline models. Coastal Engineering, 77, 14-27.

SUGUIO, K. 1973. Introdução a sedimentologia, São Paulo, Edgard Blucher/EDUSP.

UNAMURA, T. 1984. Quantitative Predictions of Beach-face Slopes. Geological Society of America Bulletin, 95, 242-245. 
TESSLER, M. G., \& GOYA, S. C. 2005. Processos Costeiros Condicionantes do Litoral Brasileiro. Revista do Departamento de Geografia, 11-23.

VAN RIJIN, L. C. 1984. Sediment transport, Part I: Bed load transport. Journal of Hydraulic Engineering, 110, 1431-1456.

VISHER G. S. 1969. Grain Size Distributions and Depositional Processes. Journal of Sedimentary Petrology, 39, 1074-1106.

WENTWORTH, C. K. 1922. A scale grade and class terms for clastic sediments. Journal of Geology, 30, 377-392.
WRIGHT, L. D. \& SHORT, A. D. 1984. Morphodynamic Variability of Surf Zones and Beaches: A Synthesis. Marine Geology, 56, 93-118.

WRIGHT, L. D., SHORT, A. D. \& GREEN, M. O. 1985. Shortterm changes in the morphodynamic states of beaches and surf zones: an empirical predictive model. Marine Geology, 62, 339-364.

Yates, M. L., Guza, R. T. \& O’Reilly, W. C. 2009. Equilibrium shoreline response: observations and modeling. Journal of Geophysical Research, 114, C09014. 